Karadeniz Uluslararası Bilimsel Dergi

Volume: 52, Winter-2021, p. (137-151)

ISSN: 1308-6200 DOI Number: https://doi.org/10.17498/kdeniz.1034096

Research Article

Received: Nov 8, 2021 | Accepted: Dec 10, 2021

This article has been checked for plagiarism.

\title{
THE TENDENCIES OF DECREASING THE INVESTING ACTIVITIES AND THE NUMBER OF JOBS IN GEORGIA AT THE BACKGROUND OF INCREASING ECONOMIC INDICATORS
}

\author{
EKONOMIK VERILERINN BÜYÜMESİ ISSIĞINDA GÜRCISTAN'A \\ YAPILAN YATIRIM SÜRECI VE İS OLANAKLARI
}

\section{ТЕНДЕНЦИИ ИНВЕСТИЦИЙ И СОЗДАНИЯ РАБОЧИХ МЕСТ В ГРУЗИИ НА ФОНЕ РОСТА ЭКОНОМИЧЕСКИХ ПОКАЗАТЕЛЕЙ}

Davit BIDZINASHVILI*

\begin{abstract}
We have heard several times recently the Government of Georgia declaring the" two-digit economical rise which is unprecented all over the world" $(12,7 \%$ in six months) which has resulted in changing the depressive background and nihilistic thinking in the country. Surely, such progress must be reflected in the well-being of the population. But what to do with the increased inflation which is much more perceptible by population than "rushing" of Georgian economy? This growth of inflation is explained by our economists as the result of wrong economic policy. As for the promises given by the National Bank in the beginning of the year 2021, about controlling the inflation and reaching the aiming results at the end of the year, they remained only as pure promises.

In order the growth of economy becomes perceptible for our population, it is necessary to lower the inflation rate to one digit, namely the best would be lower than $6 \%$ rate and if at the same time the two digital economic growth will be retained, this would be notable for the population of the country in 2022.

Active participation of Georgia in international division of labor, larger and more stable positioning of Georgian products on the World's trade map are the results of successful realization of economical reforms and state programs of the business support in the country. Key words: economic growth, foreign trade, inflation, labour market, investigations, economical policy, working places.
\end{abstract}

ÖZ

Son zamanlarda, Gürcistan hükümeti tarafindan sık sık "benzeri görülmemiş" çift haneli bir ekonomik büyümeye (6 ayda \%12,7) sahip olduğumuzu ve bunun ülkedeki nüfusun depresif geçmişini ve nihilist tutumunu değiştirdiğini açıklamaktadır. Ekonomik büyüme aynı

\footnotetext{
* ORCID: 0000-0002-2311-4110, Prof. Dr., Gori State Teaching University, Gori, Georgia, davitbidz@gmail.com
} 


\section{The Tendencies Of Decreasing The Investing Activities And The Number Of Jobs...}

zamanda nüfusun refahına da yansımalıdır, ancak nüfusun ekonomik durumu yine de fena durumda ve artan enflasyon da kendini her gün göstermektedir. Uzmanlar enflasyondaki artışı yanlış ekonomi politikalarına bağlıyor. 2021'in başlarında enflasyonun asgari seviyeye düşeceği ve ülkenin yılsonuna kadar hedefe yaklaşacağını açıklayan Merkez Bankası'nın verdiği söz iyimserliğini koruyor.

Nüfusumuzun bir şekilde ekonomik büyüme gidişatını algılaması için, enflasyonun en az tek haneli bir seviyeye ve en iyi ihtimalle \% 6'nın altına inmesi gerekiyor. Eğer ekonomik büyüme çift haneli olarak sürdürülürse 2022'ye kadar halk bu durumun yansımalarını görecektir.

Gürcistan'ın uluslararası işbölümüne aktif katılımı, Gürcü ürünlerinin dünya ticaret haritasında daha geniş ve daha sağlam konumlandırılması, son yıllarda ülkede ekonomik reformların ve devlet işletme destek programlarının başarılı bir şekilde uygulanmasının sonucudur.

Enflasyon, nüfusun ve özellikle düşük ve sabit gelirli insanların refahını doğrudan etkiler. Bununla karşı karşıya kalan sadece yoksullar değil, hemen hemen her aileyi etkileyen sosyal bir sorundur. Bu şartlar altında, insanların kendilerini güvende hissetmeleri için tek yol, gelir artış hızının enflasyondan daha yüksek olması gerektiğidir. Sadece bu durumda katlanılabilir olacak ve nüfus için daha az yük olacaktır.

Anahtar Kelimeler: Ekonomik büyüme, dış Ticaret; Şişirme, İşgücü piyasası, Yatırımlar, Ekonomik politika, iş yerleri.

\section{АННОТАЦИЯ}

В последнее время правительство Грузии часто заявляет, что у нас «беспрецедентный» двузначный экономический рост $(12,7 \%$ за 6 месяцев), и что это изменило депрессивный фон и нигилистическое отношение населения в стране. Экономический рост также должен отражаться на благосостоянии населения, но как насчет роста инфляции, которую население воспринимает сильнее, чем “брожение” экономики? Эксперты объясняют рост инфляции неправильной экономической политикой. Обещание Нацбанка, объявившего в начале 2021 года о том, что инфляция достигнет минимума и к концу года страна приблизится к целевому показателю, остается в хорошем настроении.

Чтобы наше население так или иначе воспринимало экономический рост, инфляция должна снизиться как минимум до однозначной отметки, а в лучшем случае - ниже $6 \%$ ... и если мы сохраним двузначный экономический рост, к 2022 году. население это уже почувствует.

Активное участие Грузии в международном разделении труда, более широкое и прочное позиционирование грузинской продукции на карте мировой торговли является результатом успешной реализации экономических реформ и государственных программ поддержки бизнеса в стране в последние годы.

Ключевые слова: Экономический рост; внешняя торговля; Инфляция; Рынок труда; Инвестиции; Экономическая политика; Рабочие места.

\section{Introduction}

The Corona-virus pandemic had serious negative impact on the world's economy. Many branches of economics damaged.during the year 2020-2021 the world's economy reduced substantially.

The main source of incomes for the populations of all countries is their economy. Correspondingly, growing of the country's economy is the only trustful 


\section{Davit BIDZINASHVILI}

and stable way to increase the incomes of the population. We should produce much more products and provide more services within our country's territory in order to provide well being of the population. Surely, it is possible and useful for our country to get some kinds of help from the other countries but as only one time help, also as it became usual for Georgia, it is possible to migrate to other countries and gain financial support for the other parts of the population, but the country's economy will never develop only by these ways. There does not exist any country all over the world which became rich and developed economically only by means of migrants' labor. On the contrary, immigration means draining of the labor power; and along with the demographic problems, this reduces the percentage of employable population. (https://www.helloblog.ge/story/economical growth).

According the renewed estimations, the economical growth in 2021 will show $6,5 \%$ which is much more than previous prognoses. This implies positive changes in all kinds of the economical data. At the background of the high economic growth, the budget deficit will reduce to 7, 1 percebt (today we have the 7,6 deficit). This is very important claim for stabilization of the macro-economic growth. Our prognoses contain also an optimistic scenario according which in year 2021, will be on the two-digit level and it is absolutely possible that economical activities will develop by this optimistic scenario.

The mentioned scenario takes into account rapid restauration of tourism activities, namely, on the level of 2019, which represented 40-45\%; it also takes into consideration dynamic growth of the economy in different sectors. We have distinct marks which can be observed in the 9 months data of the given year, where we see that economic growth went up to almost $45 \%$; this growth involves practically all the economic sectors.

According the renewed prognosis, the deficit of the current account improves and the dynamics of the debt reducing by the government will be faster. Founded on the these prognoses, preparation will begin for the budget changes project. (https://www.mof.ge/News/9779)

Methods of investigation: The appropriate special literature available in Georgian and foreign languages was used in the process of researching the mentioned issues along with the legislative and statutory acts, statistic information; also the methods of analysis and synthesis, induction and deduction, empiric method, sociological questionnaires and mathematical statistics were used during the researching process.

\section{The results}

We have the economic growth but nevertheless, working places are reducing and we are having serious difficulties in the social life. The population can feel the growth of economy only when there will be sufficient work and unemployment will reduce. The working people must have higher salaries in public and in business sectors as well, and at the same time, inflation will not show such high level,

The minor and medium enterprises represent the backbone of economics in 


\section{The Tendencies Of Decreasing The Investing Activities And The Number Of Jobs...}

any country. So, it is necessary to enlarge the possibilities for the financial products become available for such enterprises so that the tendencies of business growing become supported especially now, when the country is struggling against pandemics. The fact that financial debts are in the national currency will also support growth of national economy as the representatives of minor and medium business will be protected against from the currency risks.

The only way to reach the aim that our population is protected from the financial risks is in the tempo of the incomes growths wll be higher than dynamics of the prices growth.

Shortly, we can conclude that the main cause of the low level growth of our economics is not only the results of pandemics but the low level of economical development as well. It should be noted that it often happens that people can not take credits from the banks because of the strict conditions, they appeal to the micro financial organisations which give debts for higher percentage and even more, some of such organisations do it purposefully though we hope that such facts are not usual but the fact is that it happens and maybe it is resulted from the social difficulties.

For example, if we see growth in trading, agriculture, the same cannot be said about tourism. In this sphere, we have no data if people working in the sphere have any financial successes or not. We want to underline the necessity that all the branches of our economics will be successful, in each sector, in all the regions of the country - to say shortly, we need the real inclusive growth.

Our economy grows but in parallel the jobs are reducing and we are facing hard social situation. If we want our population to feel the growth of economy, the number of jobs should be increased, unemployment should reduce and the salaries should grow in the public and private sectors as well. At the same time, it is necessary to reduce the inflation rate.

The economy growth usually has its results reflected on the population especially in the developed countries. As a rule, their population see the improved situation just about in 3-6 months; unfortunately, in the countries like ours, this is not as easy. Georgian economy shows growth each month but as the working places reduce in parallel, we have a complex social environment in the country as a result. In order our population feel the economical growth, it is necessary to have more working places and reduce enemployment; salaries should become higher in public as well as in business sectors; at the same time, unemployement should reduce and inflation shuld be lowere; if we can manage to retain two-digit growth in the farther perspective, we can feel it reflected in the population, by the year 2022. If two digit inflation remains, it wil "eat up" the economic growth and our population will not feel the positive effects of the growth.

Naturally, the people;s society react to inflation and rise of prices more sharply than to economy growth. Rise of prices, taxes and so on, reflect on the people's well being immidiately; as for the economy growth, which is based on the growth of number of different enterprises, improvemints for business, growth of import and export - these factors cannot be immediately felt by the population; in order the population of the country feel and see the economic improvement as soon 


\section{Davit BIDZINASHVILI}

as possible, it is basically important to reduce inflation rates, as minimum, by $6 \%$, no less.

Despite the measures taken by the National Bank, there is no result for the population well being. This comes from the fact that Georgian National Bank prints more money notes than it is necessary - it means to provide more money to the market than necessary and it results in inflation, consequently, this problem needs to be regulated.

The pandemics influenced all the countries in the world, even the strong countries with the well developed economy and this conditioned the rise of prices all over the world.

Thus, we should be oriented on the economical development of our country and proper economy politcies, then we will be less depended on the global economic quakes, our economy will be less influenced by the global instability.

\section{Discussion}

According the global economy observation published by the International Monetary Fund, the forecast about Georgia's economy growth is possible to be the highest in 2021-2026 medium period, in the region and among the European countries.

The prognosis of the International Monetary Fund acknowledged that it is possible that Georgia will have significant economical growth. It is really important when one of our main financial partners declares that in the following 6 years Georgia will be a leader in the region by its economical growth. It will be about $5,8 \%$ growth will enable our country to overcome the negative results of the global pandemic in our country. To defeat poverty and make our economy more divert.

Georgian economy rises at the beginning of the year by higher tempo than it was predicted. It is clearly acknowledged by the statistical data, according which in January - August 2021 the economic growth showed 12\% which is higher than expected; as for the real total inner product it surpassed the pre-pandemic data of the year 2019 and so, we have an absolute growth.

The growth of inner and outer requests supports the tendency of economical rehabilitation. We have export growing, money transfers, rehabilitation of tourism. "The level of trading is higher than it was in prepandemic period. Foreign trade grew in $4,9 \%$ as compared to the previous year and export data grew in $9.0 \%$. Economic recovery was triggered by the state support programs which made development of the local production possible even in the pandemic situation the influence of which was less hard than could be and this all together supported development of the local production.

According the prognosis of the international monetary fund in 2021-2026 the growth of economy in Georgia will show up to 5,8\% which will be the highest among the European countries and the region. Already in the current year, the prognosis of growth, made by Asian development bank and other data of rating companies were significantly high.

In the data of the foreign trade published in October of the current year, quite 


\section{The Tendencies Of Decreasing The Investing Activities And The Number Of Jobs...}

good dynamics was shown and despite the pandemic situation, about 3 billion USD products were exported in 9 months of the current year; so the export showed $24 \%$ of growth. Comparing to the same situation of the year 2019, we have 9\% groth. Despite the fact that we can not give the information about the certain products, because the data was edited only today but we can suppose that in September, just as in the previous year, the main exported branch was rececling industry and among them especially Georgian wine, mineral and spring water, also industrial products. Among the exporting branches are also agricultural and mining engineering and not processed but the primary agricultural and mining industries.

According the statistic data, made by Saqstat, in September 2021 the export rate was higher in 12,8 percent as compared with the previous year and its volume became 373,6 mln US dollars.

The export data fixed in September 2021was much higher than the data of September 2019 (before pandemics), namely, the export in 2021 is higher than in September 2019 by $22.3 \%$-OOT, which shows 68.1 million US dollars.

In September the foreign trading increased by 20.1 percent that means $1,299,4$ mln US dollars..

Improvement of the macroeconomic situation in Georgia and higher business activity correspondingly is reflected in the country's foreign economical activities. Trading, and among this, the export grows up in stable way in tempo whown by two digital numbers. Besides that, the growing tempo of the export area was shown in the period January-September and also namely in September, which is much fast than the tempo of growth of the national product growth.

From the beginning of the year the growth expressed im 24.0 growth and its volume reached $2981.3 \mathrm{mln}$ US dollars. .

The data of January as well as the whole period of January-September showed higher numbers than the data in September and September-January of 2019.(22.3 and 9.0 percents, correspondingly). So, in the percent the data was 22,3 and 9\%. According this, the everyday, or 24 hours data, was 2270 thousand US dollars higher than the same data of September 2019.

Importing activities in September 2021 was 5d 1299.4 mln US dollars; altogether, in January-September - $7028.4 \mathrm{mln}$ dollars. Correspondingly, the tempo of growth was $+23.4 \%$ and $+21.6 \%$. Overlaping of import by export activities in 2021 showed 40.4 percent and in the whole period of January-September it was $42.4 \%$.

It should be noted that export in Septmber was higher than the first eight months data of the given year, by $14.5 \%$. Correspondingly import was higher for 23,1 percent and the the total data was higher than $20,5 \%$. We think that the growth of import data is a little more in comparison with the export which is largely connected to the rapid and high growth of the transporting and communication functions and also to the growth of reexport in comparison with the last year - about 20,0 growth. Daily, average growth in 24 hours volume of reexport is increased by 0.5 mln US dollars. 
External Trade (Milion USD)

\begin{tabular}{|c|c|c|c|c|c|c|c|}
\hline & 2015 & 2016 & 2017 & 2018 & 2019 & 2020 & $\begin{array}{c}2021 * \text { (January- } \\
\text { August) }\end{array}$ \\
\hline \begin{tabular}{|l|} 
External Trade \\
Turnover
\end{tabular} & 9508.4 & 9459.0 & 10802.9 & 12741.5 & 13317.6 & 11396.3 & 10009.7 \\
\hline Export (FOB) & 2204.2 & 2117.1 & 2745.7 & 3379.7 & 3798.4 & 3343.4 & 2981.3 \\
\hline Import (CIF) & 7304.2 & 7341.9 & 8057.2 & 9361.8 & 9519.2 & 8052.9 & 7028.4 \\
\hline Trade Balance & -5100.0 & -5224.7 & -5311.4 & -5 982.1 & -5720.8 & -4709.4 & -4047.1 \\
\hline Domestic export & 1602.5 & 1620.4 & 2007.8 & 2226.2 & 2324.5 & 2408.1 & 2166.1 \\
\hline
\end{tabular}

https://www.geostat.ge/en/modules/categories/35/external-trade

In September, in comparison with previous month the rate of inflation was was $0,2 \%$ and yearly inflation showed $12,3 \%$.

According the SACSTAT published data the changes of prices had great impact on the yearly inflation. These were the changes in the following groups: food and alcohol free drinks, transport, water, electricity and gas, healthcare.

According the SACSTAT in the group of food and alcohol free drinks, the prices grew on the following products:

Oil and other fat products - prices went up by $40.7 \%$

Vegetables - by $38.2 \%$

Milk, cheese and eggs - by $17.1 \%$

Sugar, jam and other sweets - by $16.6 \%$

Bread and related products - by $13.2 \%$

Mineral and spring water, alcohol-free drinks, natural juces -prices went up by $12.6 \%$-OOT

fish - by $11.5 \%$

Meat and its products - by $10.4-\%$

Coffee, tea, cocoa - by $7.1 \%$.

The tempo of inflation is permanently growing in Georgia and goes even more higher. Monthly data show that this takes place every month. All kinds of products have higher prices. According the price growing data Georgia is a leader in the region.

Inflation rate remained in two digit data. In September it was 12,3\% which 4 times more than expected. It must be said the prices on the sepaate products rose much higher such as 50,60 and $150 \%$. Food became especially expensive which drove the population to poverty situation. According these high data, we strongly doubt about methodology and trustability of the "Saqstat" company.

Comparing with the last year, the prices more notably grew up for vegetables: egg plant - $152 \$$ (the highest growth), then come cucumber - 82\%, oil $77 \%$, tomatoes $-42 \%$, carrot $-61 \%$, potatoes $-29 \%$.chcken meat $-26 \%$; medical medical pill and and remedies grow in $16-17 \%$, petrol- $42 \%$; dizel fuel $-37 \%$ and so on.

Inflation is directly worsening the level of life of the country's population, especially for the people with the low and fixed income. Here we do not mean only 


\section{The Tendencies Of Decreasing The Investing Activities And The Number Of Jobs...}

poor people. This is a serious social problem. It concerns not only the poor people but almost all the families. In such conditions in order the people feel themselves safe, the income rate should be higher than inflation. Only in such conditions it can be possible for people to endure these conditions.

It happened earlier that the prices were high in our country. But such high prices never occurred in September in the given century. In accordance with the separate positions the prices go high sometimes the process of oil, sometimes sugar, sometimes fat, corn and others. Sometimes prices go high than inflation indexes. Special attention should be paid to the prices of medicines. The bulk of the medicine products are needed by the elderly people. Inflation strikes very hard the life such people. The inflation in this field is at least $15 \%$, not 12,3 which also is very high and Georgia is positioned in the first 20 countries. It may be that this marker is not also exact and real; it can be higher. It does not matter. The main problem is that two-digit data is very high and heavy burden for Georgian people whose incomes are quite low.

Surely, inflation has very negative impact on the purchasing ability of population. The mentioned two-digit inflation is taken from the prices which grew up, as average, on 305 mentioned products. The data is even higher in the group where goods are most needed and in some instances the 100 percent inflation is even shown. Surely, the most negative impact goes to the low-income population who spend $1 / 3$ of their income is spent for food. Thus, high rate of inflation has negative impact on population even more in the conditions when nominal growth of salaries is not observed in the needed volume for their well-being. The national bank issues more lari than it is necessary for economy and this results in inflation.

On the given stage we do not have the signs of improvement in the existing situation. It is difficult to make prognoses about the problem. So far, we do not have any signs of it. The inflation rate depends what decisions and actions will be made by the National Bank or the government. The National Bank made some actions but no result. National Bank produces more money than needed. It must be regulated as soon as possible. The national Bank of Georgia prognoses about making inflation rate lower next year.

One of those whose fault is the inflation, is the National Bank. When the course of our currency was increasing, they used to persist that it would not influence for inflation. When the process was beginning, the Bank did not make any steps to slow it down and today we are where we are. Devaluation of the national currency conditioned the higher prices. We have large import and of course, devaluation of the national currency influences the prices, and first of all, on the petrol, correspondingly, we received high rate of inflation. It will be difficult to stabilize. It can not be believed that the situation improves during the year and the rate will lower to the aimed data though we hope that the national Bank will act more carefully and will take care to lower the inflation., not to be more than $6 \%$. Surely, it does nor depend on us and we all are subjects to obey the rules of markets. The oil prices were mounted on the international market and it caused the price growing up; at the same time, in highest level; at the same time, national currency course became stabilized. 


\section{Davit BIDZINASHVILI}

Consequently, by the logics, the prices of fuel should have reduced. But unfortunately, it did not happen. Importing companies, when the prices on the international market grow, react rapidly and when on the contrary, the prices of oil go down, they never lower the increased prices. The importers of oil try to have as more benefit as possible. To our mind, in such situation the oil price should have been lowered at least by 10 tetris, but it remained higher.

Unfortunately, Georgia became a country dependent on the immigrants, Their money transfers grow every year. From one side it is good but on the other side the flow of people leaving the country cannot be good for the country. This year the htransfers from emigrants prevailed in comparison with index of investments which is not good for economics. If we want to be developing and strong country it is necessary to receive as large investments as possible. This will result in strengthening our economy and inflation will reduce. We should not take care of transferring money but instead we should care to strengthen the economy so that our emigrants could return home. As for petrol and for grains, we depend on the global markets, so the price rising will always have impact on our economy and devalvation of the local currency will go up; this altogether will have very negative influence on our life and we add here currency devalvation, we will receive bad results. That is why we need stable local currency and strong economy and if the companies will work scrupulously, (we have the agency of competition in business which is obliged permanently observe the sensitive markets such as petrol market). Then we shall have less rising in prices; at any rate, if the growth will take place this will reflect in our economy but when it reduces the same will be for our prices too),

As for economy process it is really positive. It is really good to have twodigit growth and this continues during the months. And this happens in the pandemic situation. Any case, economy data depends on the proceeding situation. It is impossible to revies any economic situation apart from the pandemic situation. It is clear that in case the situation goes harder, with more prohibitions, it moves the country backwards. The prime minister of our country announces that there will not be any kind of lockdowns any more. Though the first rated problem always remains to be health conditions in the country and the lives of the population. Thus, if the situation goes up the lockdown will be necessary. We do not mean full lockdown but even minor and easier ones can influence our living conditions. Of course, our citizens are obliged to go vaccination. If the situation goes stable, in my opinion, their economy has enough strengths to go on and we are now depended not only one developed country's market but we depend on the global market and our inflation for some percent is tied to the global difficulties. We should be able to control the pandemic situation with more success but it is difficult. Turkey has quite a strong economic situation. There also exist some problems with their economy though they somehow manage to overcome the difficulties. We are now dependent not only one but on the global market. This also can be regarded as a cause for inflation.

Today inflation is the most important risk. We expect that next year inflation will go down though the most important problem today is inflation and we hope that it will be overcome at least partially the next year and it will go closer to the previous 


\section{The Tendencies Of Decreasing The Investing Activities And The Number Of Jobs...}

mark. The main problem is about refinancing in order it should not go higher; today's refinancing bid Bshould not go higher as it will be hard for our population. We think that to make balance, to my own opinion, it will be better to see that it is already the level when we shall return the inflation on the needed levels.

Of course, unemployment is the sharpest problem Beginning from the last period of the 90-ies, the number of population decreased and the number of employed people also decreased nearly 3 times, so this index corresponds to the absolute number of loss of the population.

Some hundreds of thousands of our population work abroad and thus the money transferring grow in Georgia year by year. This results the flow of the foreign currency about 1,8 billion dollars a year and this amount has already become three times larger than foreign investments. That is why the unemployment became number one problem in Georgia and the issue of restoring the lost territories has come to the second place.

The everyday domestic problems shadowed the general strategis tasks. Large part of the population struggles against elementary everyday nutrition problems and they do not have any physical or intellectual resources as well any time to struggle against higher problems. It represents a serious challenge for the state in security, stability and development perspectives.

According the last data, the rate of unemployment in Georgia is more than $22 \%$ which means that every 22 active people out of 100 in our country do not have jobs. Large part of our population went abroad to find any kind of job. Those who rest in the country simply wait for their chance. To get a job became a kind of chance, dream or something like that. It is like winning in totalizators. It must be said also that there sometimes are some requirements for jobs but there is no provision and vice versa... that means we are having structural unemployment.

What about qualified and perspective works low payment? This does not reflect only exaggerated deliveries but also to low quality working power as well, not only on the outer but on the inner markets. It cannot produce additional value in large amount.

What is our goal? We need highly qualified professional workers which are able to create high quality surplus value products in less time unit such as peculiar kind of service or product. But highly qualified working power requests high payment.

We should be able to produce as much productions as to be able to have important economy of scale which means that the proportion of rate must be economical i.e., the scale of salary to the manufactured unit would be much less and will not influence the growth of price. All countries, including our close neighbor Turkey, and the far country of Netherlands. They are focused not only on the inner market but on the world market as well. The inner market in Georgia with capacities of 3,7 mln can be compared by payment abilities with the middle Europe people requests (350-370 thousand people) but the population of Europe is totally half a billion. So, orientation on the inner market cannot be of any help. Which branches of economy should be used to make break through? 


\section{Davit BIDZINASHVILI}

According our traditions we always emphasize our wines and want to have more vineyards and sell wines but let us look at our vineyards. If we double their squares and sell our wine in the prices of French ones, which are of 40-50\% higher than ours, we should sell them for about 650-700 million dollars altogether, that is the maximum of abilities of our vineyards even if we grow them on doubled squares. Certainly, we may reach some results but only in several years for having the requests as well as realization. That is why we think that this is not the perspective we should be oriented on. We should be oriented on the scientific achievements. To have new technologies, work with leading scientific producers and enterprises, learn about technological innovations including air and cosmoses technological products, cooperating with the large and well-known air and cosmos technological enterprises will rise our economy and improve the situation even in the agricultural sector which we consider so much important for us. The best example for us s Israel which reached the level where possessing good and fertile agricultural resources is not the most important any more.

Netherlans have worse agricultural conditions in comparing with us, our country, but nevertheless they have large export of agricultural products. Their export goeas up to 100 billion dollars. Onnly flowers and plants bring about 11 bilion. This the result of using progressive scientific views and technologies.

We should invest more money in education.Not only formally - in order to give diplomas but in preparing such professionals which are now requested and will be even more in the future.In 7-8 years the requirements towards labor will fully change on the global market. New specializations will be requested. The young people who will get corresponding education will be requested and those who study or is just finishing their universities, or those who are now just beginning working, will have to adopt to the new specialties and find corresponding jobs. Many young people will have to re-prepare and get ne qualifications.

We want to overcome the impacts of unemployment not only for the purpose there would be less unemployed people but also to support rapid economy growth, to reach economical stability which is the basis for the well being and all these factors can be reached if the productions, goods or services made by the employed people, will correspond to the modern world standards. That is why, we should direct our strategy towards higher qualities, higher prices and additional costs of products correspondingly through the world market. We should subject our inner products to the above said aims organizing, producing, making business and studying processes an addition - only these factors can move up our inner production. Only considering the separate aspects without ties of economical details together will not bring any results.

If we can do all the tasks, it will drive up the whole system and will bring desired results. Discussing only several aspects without interrelations cannot bring any results.

The coronavirus pandemics and economical crisis resulted in growing the low income people sector. Today the help from the State is needed by more number of people than earlier. This fact points that nothing has improved and vice versa, the 


\section{The Tendencies Of Decreasing The Investing Activities And The Number Of Jobs...}

conditions became worse for some people. It should be noted that the number of people needing the state's help, grew up by $44,12 \%$.

According the data of August 2021, the number of people receiving the financial help increased by 67266 people. This data has never been increased up to such high digit level.

According the data of 2019 and August 2021, the State spent altogether 925.3 million laris for monetary help of socially helpless people from which 605,7 were given to them during the pandemics.

Resulting from the coronavirus pandemics Georgia experiences even more economical difficulties. The situation is serious. Pandemis is nor defeated, lost working place are not restored and without all this there is no sense to talk about improvements.

To say principally, this was not unexpected. Many working places were lost and many people have their salaries cut which influenced the population. The minor income which a person usually gets, is not enough. Most people depend on the monetary transmissions which at any rate is not enough. The people are facing deep crisis, they are using their money savings if someone has them but such people are only $0.1 \%$ in the whole population. This is very hard situation in reality.

In such economical environment, the state should support the population in the field of the communal payment and other cases though it is not enough.

It is very important at the moment that number of the persons using financial help of several types 622000 people - it is a large number; it is nearly $17 \%$ of the population. The pandemic situation only made this problem worse though it has existed even earlier.

Employment and Unemployment

\begin{tabular}{|l|c|c|c|c|c|c|c|c|c|}
\hline & 2014 & 2015 & 2016 & 2017 & 2018 & 2019 & 2020 & $\begin{array}{c}2021 \\
\text { I } \\
\text { Quarter }\end{array}$ & $\begin{array}{c}2021 \\
\text { II } \\
\text { Quarter }\end{array}$ \\
\hline $\begin{array}{l}\text { Labour force } \\
\text { Active } \\
\text { population), } \\
\text { thousand } \\
\text { persons }\end{array}$ & 1629.0 & 1675.6 & 1653.8 & 1641.4 & 1605.2 & 1572.8 & 1523.7 & 1447.2 & 1559.1 \\
\hline $\begin{array}{l}\text { Employed, } \\
\text { thousand } \\
\text { persons }\end{array}$ & 1255.0 & 1308.5 & 1294.5 & 1286.9 & 1296.2 & 1295.9 & 1241.8 & 1129.7 & 1214.6 \\
\hline $\begin{array}{l}\text { Unemployed, } \\
\text { thousand } \\
\text { persons }\end{array}$ & 374.0 & 367.2 & 359.2 & 354.5 & 309.0 & 276.9 & 281.9 & 317.5 & 344.6 \\
\hline $\begin{array}{l}\text { Unemployed, } \\
\text { thousand } \\
\text { persons }\end{array}$ & 23.0 & 21.9 & 21.7 & 21.6 & 19.2 & 17.6 & 18.5 & 21.9 & 22.1 \\
\hline
\end{tabular}

https://www.geostat.ge/en/modules/categories/683/EmploymentUnemployment

The labor market and education sphere are closely correlated which results in necessity to discuss these spheres together. The more high level education is 


\section{Davit BIDZINASHVILI}

available, the more qualified manpower we will have on the labor market and this will reflect through the labor payment. We have positive correlations between education and job salaries spheres. This is determined by investigations. People who are on the higher levels of the education have higher salaries in average. (For example, Mincer, 1997; Deschênes, 2006). The back effect of education has been changed considerably through the last period of times. The additional steps of education enlarges the possible payment when working and lowers the risks of unemployment (Murphy and Welch, 1989:17-26.; Katz and Murphy, 1992:35-78.; Mincer, 1991:1-18). Besides, in the society, where most part of people has higher education, unemployment is lower The request for the low qualification workers are in minority and during some time, high qualification request grows especially in the increasing automatisation of work.(Acemoglu, 2002:7-72.; Frey and Osborne, 2017:254-280) According the statistical data the rate of unemployment in 2017, among the not fully educated working power was $6,5 \%$, in the school graduated

population $4,6 \%$, bachelor degree educated people $2,5 \%$, and in the more higly educated part of population - 2\% (BLS Report, 2018). The same tendency is observed in European countries: 13.9\% of unemployment in case of not fully educated, $6 \%$ - full general education, and $4,2 \%$ in case of higher education (Eurostat, 2018). Can we make the same rating in case of Georgia - that is the question. It should be also said that alongside with the growth of education, the inequalities of levels of society grows up as well. (Lemieux, 2006). Beginning drom the 90 -ies of the last century, it can be observed that differemces between highly qualified and less qualified labor have been growing up because of the difference in educational levels and lessening of requests to the not highly educated and qualified workers. (Goldin and Katz, 2007:135-165). The salaries as well, in the last period, differ from each other which lessens the amount of so called medium rate workers and rises the index of inequalities. the importance of high quality education permanently grows in personal or along with the country's successful development.

As about the investments, Georgia, unfortunately, has large failure. According the precise data, in 2020 the investments reduced by more than $57 \%$ comparing with the previous year; its total volume turned out to be for 7,3\% less than usual. It can be caused by several factors, but it is important that the state should find out the resources and ways to improve the situation. The active steps should be made towards improvement even if it became necessary to take the international debt though our country's debts are on the critical point.

Reducing of investments is the echo of the global crisis and it is the result of the pandemic. We observe lessening of global requirements, interrelations and other ties established for several ten years periods between the countries; This also results in lessening of activities and economical ties between large eeconomical institutions. The facts happen not only in Georgia but among several well developed countries. Now we have a kind of investment reducing to $45 \%$.We have a kind of investment deficit and hungerthough to tell the truth many countries to improve the conditions, business environment, tax policies investment conditions - all these parametres were remained and even improveB ; such economics became again attractive and in such 


\section{The Tendencies Of Decreasing The Investing Activities And The Number Of Jobs...}

situatations some countries became additional concurents for Georgia; that is why it is necessary to practice liberalization in order to attract the countries to do investments here. We need more liberalization policies.

According the precise data, the direct foreign investments in Georgia were expressed in 2020 as $\$ 572$ millions which is $57.2 \%$ less than in 2019 and $7.3 \%$ less than predicted data of 2020 .

As it is said in the information spread by the national statistic centres, the main cause of lessening the income flow of the direct foreign investments was the fact of delivering some enterprises to the property of Georgia's resident which caused cutting the investments to $\$ 283 \mathrm{mln}$.

\section{REFERENCES}

1. 1. Mincer, J. (1997). "Changes in Wage Inequality, 1970-1990." Research in Labor Economics. New York;

2. Deschênes, O. (2006). Unobserved ability, comparative advantage, and the rising return to college in the United States, 1979-2002, Galifornia (UC SANTA BARBARA);

3. Murphy, K., Welch, F. (1989). Wage Premiums for College Graduates. Recent Growth and Possible Explanations. Educational Researcher, volume: 18 issue: 4, American Educational Research Association, Chicago;

4. Katz, L., Murphy, K. (1992). Changes in Relative Wages, 1963-1987: Supply and Demand Factors. The Quarterly Journal of Economics, Vol. 107, No. 1, Washington;

5. Mincer, J. (1991). Education and unemployment (No. w3838). National bureau of economic research. Massachusetts;

6. Acemoglu, D. (2002). Technical change, inequality, and the labor market. Journal of Economic Literature, vol. 40, no. 1, New York;

7. Frey, C. B., Osborne, M. A. (2017). The future of employment: How susceptible are jobs to computerization? Technological Forecasting and Social Change. Volume 114,OREBRO UUNIVERSITET;

8. Manyika, J., Chui, M., Miremadi, M., Bughin, J., George, K., Willmott, P. and Dewhurst, M. (January, 2017). Harnessing automation for a future that works. McKinsey Quarterly, MCKINSEY GLOBAL INSTITUTE, San Francisco;

9. United States Department of Labor. Bureau of Labor Statistics Report. <https://www.bls.gov/news.release/empsit.t04.htm> Washington;

(05.08.2018),

10. Eurostat. (2018). Unemployment rates of the population aged 25-64 by educational attainment level. <http://ec.europa.eu/eurostat/web/productsdatasets/-/tps00066>(05.08.2018), Brüksel;

11. Lemieux, T. (2006). "Postsecondary Education And Increasing Wage Inequality," American Economic Review, v96 (2,May), Massey University of New Zealand;

12. Goldin, C., Katz, L. F. (2007). "Long-Run Changes in the Wage Structure: 


\section{Davit BIDZINASHVILI}

Narrowing, Widening, Polarizing." Brookings Papers on Economic Activity 2, Brookings (USA);

13. Bichia Q. (2018). ,The danger of degradation of education system and labor market in the case of misaligned motivations"; International ScientificPractical Journal - ,, Globalization and Business“, №6, Tiflis;

14. https://www.helloblog.ge/story/economical growth

15. https://www.mof.ge/News/9779

16. https://www.geostat.ge/ka

17. https://www.geostat.ge/en/modules/categories/35/external-trade

18. https://www.geostat.ge/en/modules/categories/683/EmploymentUnemployment 